\title{
ELECTROPHYSIOLOGIC ASSESSMENT OF AUDITORY FUNCTION IN CHILDREN WITH AUTISM AND ATTENTION- DEFICIT AND HYPERACTIVITY DISORDER
}

\author{
Amira M. El Shennawy ${ }^{1}$, Mostafa El Khosht ${ }^{1}$, Heba Ghannoum², Nagwa Abd El Meguid² \\ ${ }^{1}$ Department of Otolaryngology, Audiology Unit, Faculty of Medicine, Cairo University, Cairo, Egypt \\ ${ }^{2}$ National Research Centre, Cairo, Egypt
}

Corresponding author: Amira M. El Shennawy, Department of Otolaryngology, Audiology Unit, Faculty of Medicine, Cairo University, Cairo, Egypt, e-mail: amira.doc75@outlook.com

\begin{abstract}
Background: Autism and attention-deficit and hyperactivity disorder (ADHD) are neurodevelopmental disorders sharing some developmental deficits and differing in others. The aim of this study was to specify the auditory phenotype in terms of peripheral and central hearing abilities through the use of objective and subjective assessment methods. The goal was to identify alterations in the central and peripheral auditory systems, especially those involving language and cognitive alterations, since hearing impairment can compromise language acquisition and the rehabilitation process.
\end{abstract}

Material and Methods: Exactly 60 subjects were included in this study. They were divided into 30 subjects and 30 controls, and the study group was subdivided into 15 subjects with ADHD and 15 suffering with autism. All cases were given pure tone audiometry, speech tests, and click-evoked ABR and P300 tests.

Results: Both study groups showed impaired subcortical encoding of speech, which was highly disrupted in the autistic group. The ADHD group showed delayed offset responses. Both groups had delayed P300 latencies and diminished amplitudes, which were most marked in the autistic group.

Conclusions: ADHD and autism involve impaired subcortical encoding of speech and impaired cognition, conditions that are more severe in autistic children.

Keywords: autism • attention-deficit and hyperactivity disorder • auditory processing • P300 • speech ABR

EVALUACIÓN ELECTROFISIOLÓGICA DE FUNCIONES AUDITIVAS EN NIÑOS CON EL AUTISMO Y EL DÉFICIT DE ATENCIÓN E HIPERACTIVIDAD

\section{Resumen}

Antecedentes: El autismo y el déficit de atención e hiperactividad (TDAH, ADHD en inglés) son enfermedades de desarrollo neurológico que se parecen en algunos aspectos de los trastornos, y en otros, a su vez, se difieren. El objetivo del presente estudio ha sido el de especificar el fenotipo auditivo en referencia a la audición periférica y central, utilizando los métodos de evaluación tanto objetivos, como y subjetivos. Otro objetivo ha sido también la identificación de los cambios en el sistema auditivo periférico y central, sobre todo los relacionados con el idioma o los problemas cognitivos, dado que los trastornos auditivos afectan a las competencias lingüísticas y el proceso de rehabilitación.

Materiales y métodos: En el estudio han participado 60 personas, la mitad de los cuales eran pacientes, y el resto eran el grupo de control. El grupo de evaluación fue dividido en 15 pacientes con el síndrome TDAH (ADHD en inglés) y 15 con el autismo. En estas personas se realizaron las pruebas de la audiometría de tonos puros, pruebas de lenguaje, mediciones de los potenciales auditivos del tronco cerebral (ABR) evocados mediante el estímulo tipo crujido y las mediciones de los potenciales P300.

Resultados: En ambos grupos se pudieron observar las disfunciones subcorticales de la codificación del idioma, y en el grupo de personas con el autismo se observaron grandes deficiencias en este campo. En el grupo de pacientes con TDAH se observó la respuesta tardía a una parada del estímulo. En ambos grupos se dio el retraso de latencia y la reducción de la amplitud del potencial P300, lo que, a su vez, se pudo claramente observar en el grupo de personas con el autismo.

Conclusiones: Tanto en el caso de TDAH; como y del autismo, se pueden observar las disfunciones subcorticales del sistema de la codificación del habla y los problemas cognitivos, que, sin embardo, son más serios en el caso de los niños que sufren el autismo.

Palabras clave: autismo • TDAH (trastorno de déficit de atención e hiperactividad) • procesamiento auditivo • P300 • potenciales auditivos del tronco cerebral evocados por el habla (speech ABR) 


\title{
ЭЛЕКТРОФИЗИОЛОГИЧЕСКАЯ ОЦЕНКА СЛУХОВОЙ ФУНКЦИИ У ДЕТЕЙ С АУТИЗМОМ И СИНДРОМОМ ДЕФИЦИТА ВНИМАНИЯ И ГИПЕРАКТИВНОСТИ
}

\begin{abstract}
Изложение
Фон: Аутизм и синдром дефицита внимания и гиперактивности (СДВГ) - это нарушения психического развития, которые на некоторых уровнях расстройств подобные, на других - разные. Цель настоящей работы - спецификация слухового фенотипа в области периферического и центрального слуха путем использования объективных и субъективных методов оценки. Целью являлась также идентификация изменений в центральной и периферической слуховой системе, в особенности тех, которые касаются речевых или познавательных проблем, потому что расстройства слуха влияют на речевые умения и процесс реабилитации.
\end{abstract}

Материал и методы: В исследовании взяли участие 60 человек, при этом половина это пациенты, а остальные контрольная группа. Экспериментальная группа была разделена на две группы, в одной - 15 пациентов с СДВГ, в другой - 15 с аутизмом. У них были проведены исследования тональной аудиометрии, речевые тесты, измерения слуховых стволомозговых потенциалов (ABR), вызванных с помощью импульса типа "треск", а также измерения потенциалов Р300.

Результаты: В обеих группах появились подкорковые нарушения системы кодирования речи, при этом в группе детей с аутизмом обнаружены значительные нарушения в этой области. В группе пациентов с СДВГ появлялись замедленные ответы на отключение импульса. В обеих группах появилось замедление латенции и снижение амплитуды потенциала Р300, это в свою очередь было особенно четким в группе детей с аутизмом.

Выводы: Как в случае СДВГ, так и в случае аутизма появляется подкорковое нарушение системы кодирования речи и познавательные проблемы, которые однако в случае детей с аутизмом - более серьезные.

Ключевые слова: аутизм • СДВГ (синдром дефицита внимания и гиперактивности) • слуховая обработка • Р300 - слуховые стволомозговые потенциалы, вызванные с помощью речи (speech ABR)

\section{OCENA ELEKTROFIZJOLOGICZNA FUNKCJI SŁUCHOWYCH U DZIECI Z AUTYZMEM ORAZ ZESPOŁEM NADPOBUDLIWOŚCI PSYCHORUCHOWEJ}

\section{Streszczenie}

Tło: Autyzm i zespół nadpobudliwości psychoruchowej (ADHD) są schorzeniami neurorozwojowymi, które na niektórych płaszczyznach zaburzeń są podobne, na innych - różne. Celem niniejszej pracy była specyfikacja słuchowego fenotypu w zakresie słuchu obwodowego i centralnego poprzez wykorzystanie obiektywnych i subiektywnych metod oceny. Celem była również identyfikacja zmian w centralnym i obwodowym systemie słuchowym, szczególnie tych, które dotyczą problemów językowych lub poznawczych, jako, że zaburzenia słuchu wpływają na umiejętności językowe i proces rehabilitacji.

Materiał i metody: W badaniu udział wzięło 60 osób, z czego połowa to pacjenci, a pozostali stanowili grupę kontrolną. Grupa badawcza została podzielona na 15 pacjentów z ADHD i $15 \mathrm{z}$ autyzmem. Wykonano u nich badania audiometrii tonalnej, testy mowy, pomiary słuchowych potencjałów pnia mózgu (ABR) wywołanych za pomocą bodźca typu trzask oraz pomiary potencjałów P300.

Wyniki: Obie grupy wykazały podkorowe zaburzenia systemu kodowania mowy, z czego w grupie osób z autyzmem stwierdzono duże zakłócenia w tym obszarze. Grupa pacjentów z ADHD wykazywała opóźnione odpowiedzi na wyłączenie bodźca. U obu grup wystąpiło opóźnienie latencji i obniżenie amplitud potencjału P300, co z kolei było szczególnie wyraźne w grupie osób $\mathrm{z}$ autyzmem.

Wnioski: Zarówno w przypadku ADHD jak i autyzmu występuje podkorowe zaburzenie systemu kodowania mowy oraz problemy poznawcze, które jednak w przypadku dzieci z autyzmem są poważniejsze.

Słowa kluczowe: autyzm • ADHD (zespół nadpobudliwości psychoruchowej) • przetwarzanie słuchowe • P300 •słuchowe potencjały pnia mózgu wywołane za pomocą mowy (speech ABR) 


\section{Background}

Neuro-developmental disorders involve impaired development of the brain and central nervous system. More specifically, the term refers to any disorder of brain function that affects emotion, learning ability, and memory and which reveals itself as the individual grows [1]. The term neuro-developmental disorder can be used in two ways. The first refers to conditions affecting children's neurological development with a known genetic or acquired etiology. The second refers to conditions of presumed multi-factorial etiology in which certain aspects of neurodevelopment are selectively impaired; this includes such conditions as autism spectrum disorder, developmental dyslexia, and attention-deficit and hyperactivity disorder (ADHD) [2].

Autism is a neurodevelopmental disorder that impairs social skills, delays language development, and results in repetitive behaviors and restricted interests which impede academic and social involvement [3]. Children with autistic features experience various forms of abnormal auditory perception such as hyperacusis and poor speechin-noise performance [4].

Russo and colleagues [5] reported that children with autism exhibited deficits in both the neural synchrony (timing) and phase locking (frequency encoding) of speech sounds. In comparison to typically developing controls they also exhibited reduced magnitude and fidelity of speech-evoked responses and greater degradation of responses by background noise. The transduction of speech is disrupted due to an inability to accurately process either filter cues, which help to distinguish between consonants and vowels, or source cues, which help to determine speaker identity and intent. The authors claimed their data support the idea that language impairment in autism is due to abnormalities in the brainstem's processing of speech.

Attention deficit hyperactivity syndrome (ADHD) is one of the most common psychiatric disorders with a worldwide prevalence of $5-9 \%$. It is characterized by a continuous pattern of inattentive, hyperactive, and impulsive behavior and is often co-morbid with other psychiatric disorders. Patients with ADHD have impaired academic, executive, and social functions [6]. It has been suggested that auditory processing disorders (APD) and ADHD may be the same entity with slightly differing symptoms, yet most studies comparing both have shown that while they partly overlap they remain distinct entities [7].

Musiek and Chermak [8] suggested that the relationship between attention and auditory processing could be viewed within a top-down and bottom-up information processing model. The inability to sustain sufficient attention to auditory stimuli might cause auditory processing deficits (i.e. top-down); conversely, deficient auditory processing might impair attention (i.e. bottom-up). Consistent with a bottom-up model, attention is driven by incoming sensory stimulation and garnered by properly integrated and processed sensory stimuli. If acoustic stimuli are not properly processed, as occurs in APD, then attention cannot be optimally focused on these stimuli.
As previously shown, autism and ADHD involve some kind of auditory pathology, although the details of whether it is peripheral or central and how it impacts on cognitive function have not been clearly demonstrated. By using both objective and subjective assessment methods and comparing their outcomes, it may be possible to identify certain alterations in either the central or peripheral auditory systems. If hearing deficits in this special population could be related to compromised language acquisition this would be valuable to the rehabilitation process.

This work was designed to characterize the auditory phenotype and the scope of hearing impairment in attention deficit hyperactivity syndrome (ADHD) and autism patients. In addition, we assessed subcortical processing of complex sounds using speech $\mathrm{ABR}$, and assessed cognitive development by means of event-related potentials (P300).

\section{Material and methods}

This study was conducted on 60 children who were divided into a control group and a study group. They were recruited from the outpatient clinic for autistic children at the special needs and autism disorders clinic, National Medical Research Center of Excellence, Research Center, Egypt. Ages of participants ranged between 5 to 12 years. The study was approved by the medical ethical committees of the National Research Centre and Cairo University Hospitals. An informed consent was taken from the caregivers of the patients.

I - Control group comprised 30 typically developing children with normal hearing and language development. For each test normal limits were those set by the Audiology unit of Cairo University.

II - Study group comprised:

A - 15 children diagnosed with ADHD, either of the inattentive type or combined type. All children met the criteria of ADHD according to the Statistical Manual of Mental Disorders, 4th edition (DSM-IV) [9]. Confirmation of diagnosis was obtained by means of the revised Conners Parent Rating Scale (CPRS-R) [10].

B - 15 children diagnosed with autism, all diagnoses were based upon DSM-IV after extensive diagnostic evaluation. All included children were administered the Autism Diagnostic Interview Revised (ADI-R) where they all met the ADI-R criteria for autism [11] and the Childhood Autism Rating Scale (CARS) [12] through a trained rater.

All cases were subjected to a detailed assessment protocol which included a thorough medical history, pedigree construction and analysis of three consecutive generations, complete general examination, thorough reviewing of prior records, and otoscopic examination. In addition, audiological testing was done at the audiology outpatient unit of Kasr Alainy Hospital, Cairo University.

1. Pure tone audiometry/conditioned play audiometry. Audiometry was in the form of air and bone conduction testing (age-based) and speech reception threshold (performed whenever possible depending on the child's reliability and cooperation). For this test a twochannel Grason-Stadler model 6 audiometer was used. 
2. Immitance. Single frequency tympanometry with a probe tone of $226 \mathrm{~Hz}$ and acoustic reflex thresholds for ipsilateral stimuli by pure tones at 500,1000, 2000, and $4000 \mathrm{~Hz}$ were performed using a Madsen Zodiac 901 immittance meter.

3. Click-evoked auditory brain stem response (ABR). Threshold detection at 2 and $4 \mathrm{kHz}$ was assessed. Subjects were examined while lying comfortably on a bed. Three electrodes were attached to the skin: active to the forehead, reference to the mastoid of the stimulated ear, and ground to the contralateral mastoid (resistance was kept below $5 \mathrm{k} \Omega$ ). Rarefaction click stimulus with a duration of $100 \mu$ s and repetition rate of 21 pulses/second was used at $90 \mathrm{~dB}$ nHL intensity with 10/20 dB descending steps until disappearance of wave $\mathrm{V}$. Recording was ipsilateral using a time window of $10 \mathrm{~ms}$, amplifier bandpass filter was $100-2500 \mathrm{~Hz}$, sweep count of accepted responses was 2000 sweeps, from which the absolute latencies of waves I, III, and $\mathrm{V}$ were calculated.

4. Speech-evoked auditory brainstem response. Active electrode was placed on the forehead, reference electrode on the linked mastoid, and ground electrode on the other mastoid. During testing, the child rested comfortably on a bed, watching a cartoon movie (sound level of the movie was adjusted to be less than $40 \mathrm{~dB}$ HL). The stimulus used was the synthesized syllable / $\mathrm{da} /$ of $40 \mathrm{~ms}$ duration with alternating polarity, presented at an intensity of $80 \mathrm{~dB} \mathrm{nHL}$ and rate of $13.1 / \mathrm{sec}$. The stimulus consisted of an initial noise burst during the first $10 \mathrm{~ms}$ and formant transition between the consonant and a steady-state vowel. Circumaural headphones were used to deliver the stimulus. A total number of 4000 sweeps were collected with a bandpass filter of $100-3000 \mathrm{~Hz}$ and analysis period of 75 ms including $15 \mathrm{~ms}$ pre-stimulus recording. An artifact criterion of $\pm 31 \mu \mathrm{V}$ was applied to reject epochs that contained myogenic artifacts. Two blocks of 2000 artifact-free sweeps were recorded. Recordings were obtained from the right ears only. This approach was based on the work of Akhoun et al. [13] who showed no ear differences in speech ABR.

5. P300. An "oddball paradigm" was used in which $20 \%$ of the tones were "target" (rare), while the remaining were "non-target" (frequent). The target tones were $2000 \mathrm{~Hz}$ while non-target tones were $500 \mathrm{~Hz}$ delivered at a rate of $1.1 / \mathrm{sec}$. Tones had a $10 \mathrm{~ms}$ rise/fall time, $100 \mathrm{~ms} \mathrm{du}-$ ration and intensity of $80 \mathrm{~dB} \mathrm{nHL}$. The signal was filtered with a bandpass of $1-30 \mathrm{~Hz}$ and the time window ranged from 0 to $500 \mathrm{~ms}$. P300 was identified as the positive deflection during 250-500 ms. Scalp Ag/ $\mathrm{AgCl}$ electrodes were used with the active electrode at $\mathrm{Fz}$ referenced to ear mastoids. Instructions were given before the test and the subject was asked to count in silence the number of rare tones presented. Data for two trials were obtained, stored, and averaged by computer. With some patients, especially from the autistic group, training and reinstructing with the help of the caregiver was needed prior to recording. Auditory brainstem responses (click and speech) and P300 tests were done using an Intelligent Hearing System SmartEP.
Table 1. Mean and standard deviation of pure tone audiometric thresholds for the control group and the two study groups

\begin{tabular}{lrrr}
\hline & Control & ADHD & Autism \\
\hline $250 \mathrm{~Hz}$ & & & \\
Mean & 10.5 & 15.3 & 14.7 \\
SD & 4.4 & 5.2 & 4.0 \\
\hline S00 Hz & & & \\
Mean & 11.0 & 15.3 & 15.3 \\
SD & 4.6 & 5.2 & 3.5 \\
\hline 1000 Hz & & & \\
Mean & 10.8 & 17.3 & 15.3 \\
SD & 4.4 & 5.6 & 4.0 \\
\hline $2000 \mathrm{~Hz}$ & & & \\
Mean & 11.5 & 18.0 & 16.3 \\
SD & 4.6 & 5.6 & 3.5 \\
\hline 4000 Hz & & & \\
Mean & 13.7 & 19.7 & 18.0 \\
SD & 4.7 & 5.2 & 2.5 \\
\hline S000 Hz & & & \\
Mean & 14.8 & 20.3 & 18.3 \\
SD & 4.6 & 4.8 & 3.1 \\
\hline
\end{tabular}

\section{Statistical analysis}

Data was entered into Microsoft Excel (2010) for Windows, then transferred to the Statistical Package of Social Science Software program, version 21 (SPSS) for statistical analysis. Data was summarized using range, mean, standard deviation, and median for quantitative variables. Comparison between groups was performed using the KruskalWallis test followed by a pairwise Mann-Whitney test. $P$ values less than 0.05 were considered statistically significant, and less than 0.01 were considered highly significant.

\section{Results}

Demographic results

Mean age of ADHD patients was $7.47 \pm 1.88$ years and for autistic patients $7.27 \pm 1.90$ years. There were more males than females with a ratio of $3: 1$. There were $86.7 \%$ males and $13.3 \%$ females in the ADHD group and $80 \%$ males and $20 \%$ females among the autistic group. The controls were age and gender matched. Among the ADHD group, 10 patients were of the combined type and 5 were of the inattentive type.

\section{PTA results}

All ADHD subjects showed normal hearing sensitivity bilaterally except for 2 patients (one had bilateral mild sensorineural hearing loss and the other had slight conductive hearing loss in the right ear). Play conditioned audiometry could be performed on only 10 autistic subjects and they all showed bilateral normal hearing. The ABR test showed normal hearing threshold for the 15 autistic subjects (Table 1). 
Table 2. Speech ABR wave latencies among the control and two study groups

\begin{tabular}{|c|c|c|c|c|c|}
\hline $\begin{array}{l}\text { Latency } \\
\text { (ms) }\end{array}$ & Control (C) & ADHD (AD) & Autism (AU) & $\begin{array}{c}P \text { value } \\
\text { (Kruskal-Wallis) }\end{array}$ & $\begin{array}{l}\text { Pairwise } P \text { value } \\
\text { (Mann-Whitney) }\end{array}$ \\
\hline \multicolumn{6}{|l|}{$\mathbf{V}$} \\
\hline Range & $5.13-7.88$ & $5.5-10.38$ & $5.25-10.13$ & 0.084 & $C$ vs. $A D=0.16$ \\
\hline Mean $\pm S D$ & $6.34 \pm 0.76$ & $7.14 \pm 1.5$ & $7.15 \pm 1.09$ & & C vs. $A U=0.08$ \\
\hline Median & 6.18 & 6.88 & 7.00 & & $A D$ vs. $A U=0.51$ \\
\hline \multicolumn{6}{|l|}{ A } \\
\hline Range & $6.8-10.75$ & $7.1-12.63$ & $5.75-12.38$ & 0.203 & C vs. $A D=0.54$ \\
\hline Mean \pm SD & $8.43 \pm 1.2$ & $8.98 \pm 1.78$ & $9.55 \pm 1.92$ & & $C$ vs. $A U=0.09$ \\
\hline Median & 8.21 & 8.38 & 9.13 & & $A D$ vs. $A U=0.25$ \\
\hline \multicolumn{6}{|l|}{ V/A slope } \\
\hline Range & $0.08-0.53$ & $0.07-0.45$ & $0.03-0.4$ & 0.569 & $C$ vs. $A D=0.57$ \\
\hline Mean \pm SD & $0.25 \pm 0.14$ & $0.22 \pm 0.12$ & $0.19 \pm 0.11$ & & C vs. $A U=0.41$ \\
\hline Median & 0.23 & 0.21 & 0.18 & & $A D$ vs. $A U=0.41$ \\
\hline \multicolumn{6}{|l|}{ C } \\
\hline Range & $14.5-20.63$ & $12.68-26.88$ & $15.75-23.63$ & 0.02 & $C$ vs. $A D=0.22$ \\
\hline Mean \pm SD & $18.15 \pm 2.08$ & $17.13 \pm 3.71$ & $19.46 \pm 2.19$ & & $C$ vs. $A U=\mathbf{0 . 0 2}$ \\
\hline Median & 19.25 & 16.63 & 20 & & $A D$ vs. $A U=\mathbf{0 . 0 2}$ \\
\hline \multicolumn{6}{|l|}{ D } \\
\hline Range & $20.63-29.24$ & $21.5-31.38$ & $26.75-33.25$ & $<0.001$ & $C$ vs. $A D=0.49$ \\
\hline Mean \pm SD & $26.67 \pm 2.66$ & $26.27 \pm 2.6$ & $29.22 \pm 1.47$ & & C vs. $A U=<0.001$ \\
\hline Median & 27.75 & 26.13 & 29.00 & & $A D$ vs. $A U=<0.001$ \\
\hline \multicolumn{6}{|l|}{ E } \\
\hline Range & $24.63-39.1$ & $31.32-42.88$ & $34.63-41.25$ & 0.019 & C vs. $A D=0.9$ \\
\hline Mean \pm SD & $34.75 \pm 3.76$ & $35.73 \pm 3.03$ & $37.56 \pm 1.73$ & & C vs. $A U=0.006$ \\
\hline Median & 36.38 & 35.88 & 37.63 & & $A D$ vs. $A U=\mathbf{0 . 0 3}$ \\
\hline \multicolumn{6}{|l|}{$\mathbf{F}$} \\
\hline Range & $38.3-46.75$ & $38.4-52.63$ & $45-50$ & $<0.001$ & $C$ vs. $A D=0.17$ \\
\hline Mean \pm SD & $44.11 \pm 2.51$ & $45.13 \pm 3.27$ & $47.09 \pm 1.27$ & & C vs. $A U=<0.001$ \\
\hline Median & 44.25 & 45.00 & 47.25 & & $A D$ vs. $A U=\mathbf{0 . 0 0 4}$ \\
\hline \multicolumn{6}{|l|}{0} \\
\hline Range & $47.81-56.13$ & $49.75-58.63$ & $52.88-58.3$ & $<0.001$ & $C$ vs. $A D=\mathbf{0 . 0 0 5}$ \\
\hline Mean \pm SD & $51.49 \pm 2.41$ & $54.4 \pm 2.34$ & $56.22 \pm 1.09$ & & C vs. $A U=<0.001$ \\
\hline Median & 50.38 & 54.13 & 56.38 & & $A D$ vs. $A U=\mathbf{0 . 0 0 6}$ \\
\hline
\end{tabular}

\section{Click ABR test results}

No statistical significant differences were found between the latencies of waves I, III, and V among the 3 groups.

\section{Speech ABR test results}

Table 2 shows no statistical significant difference among the three study groups regarding the latencies of waves 
El Shennawy et al. - Electrophysiologic assessment of auditory function in children with autism...

Table 3. Speech ABR wave amplitudes among the control group and the two study groups

\begin{tabular}{|c|c|c|c|c|c|}
\hline $\begin{array}{c}\text { Amplitude } \\
(\mu \mathrm{v})\end{array}$ & Control (C) & ADHD (AD) & Autism (AU) & $\begin{array}{c}\text { P value } \\
\text { (Kruskal Wallis) }\end{array}$ & $\begin{array}{l}\text { Pairwise P value } \\
\text { (Mann Whitney) }\end{array}$ \\
\hline \multicolumn{6}{|l|}{$\mathbf{v}$} \\
\hline Range & $0.06-0.28$ & $0.07-0.28$ & $0.07-0.26$ & 0.75 & C vs. $A D=0.44$ \\
\hline Mean \pm SD & $0.19 \pm 0.07$ & $0.16 \pm 0.07$ & $0.18 \pm 0.06$ & & C vs. $A U=0.78$ \\
\hline Median & 0.18 & 0.18 & 0.2 & & $A D$ vs. $A U=0.74$ \\
\hline \multicolumn{6}{|l|}{ A } \\
\hline Range & $0.12-0.49$ & $0.09-0.29$ & $0.08-0.24$ & 0.016 & $C$ vs. $A D=\mathbf{0 . 0 2}$ \\
\hline Mean \pm SD & $0.25 \pm 0.10$ & $0.18 \pm 0.06$ & $0.16 \pm 0.05$ & & $C$ vs. $A U=\mathbf{0 . 0 1}$ \\
\hline Median & 0.23 & 0.18 & 0.18 & & $A D$ vs. $A U=0.62$ \\
\hline \multicolumn{6}{|l|}{ C } \\
\hline Range & $0.13-0.38$ & $0.11-0.31$ & $0.09-0.24$ & 0.001 & $C$ vs. $A D=\mathbf{0 . 0 4 8}$ \\
\hline Mean \pm SD & $0.24 \pm 0.08$ & $0.19 \pm 0.06$ & $0.14 \pm 0.05$ & & C vs. $\mathrm{AU}=<0.001$ \\
\hline Median & 0.24 & 0.18 & 0.14 & & $A D v s . A U=\mathbf{0 . 0 4}$ \\
\hline \multicolumn{6}{|l|}{ D } \\
\hline Range & $0.16-0.61$ & $0.09-0.48$ & $0.08-0.23$ & $<0.001$ & C vs. $A D=0.09$ \\
\hline Mean \pm SD & $0.35 \pm 0.14$ & $0.27 \pm 0.11$ & $0.16 \pm 0.05$ & & C vs. $\mathrm{AU}=<0.001$ \\
\hline Median & 0.34 & 0.26 & 0.16 & & $A D$ vs. $A U=\mathbf{0 . 0 0 2}$ \\
\hline \multicolumn{6}{|l|}{$\mathbf{E}$} \\
\hline Range & $0.09-0.41$ & $0.08-0.3$ & $0.07-0.2$ & $<0.001$ & C vs. $A D=0.06$ \\
\hline Mean \pm SD & $0.27 \pm 0.08$ & $0.21 \pm 0.07$ & $0.14 \pm 0.04$ & & C vs. $A U=<0.001$ \\
\hline Median & 0.28 & 0.22 & 0.13 & & $A D$ vs. $A U=\mathbf{0 . 0 0 4}$ \\
\hline \multicolumn{6}{|l|}{$\mathbf{F}$} \\
\hline Range & $0.19-0.48$ & $0.12-0.32$ & $0.09-0.21$ & $<0.001$ & C vs. $A D=0.08$ \\
\hline Mean \pm SD & $0.32 \pm 0.11$ & $0.24 \pm 0.06$ & $0.15 \pm 0.04$ & & C vs. $\mathrm{AU}=<0.001$ \\
\hline Median & 0.31 & 0.26 & 0.15 & & $A D$ vs. $A U=<0.001$ \\
\hline \multicolumn{6}{|l|}{0} \\
\hline Range & $0.19-0.49$ & $0.15-0.32$ & $0.1-0.24$ & $<0.001$ & $C v s . A D=\mathbf{0 . 0 1}$ \\
\hline Mean \pm SD & $0.33 \pm 0.09$ & $0.25 \pm 0.05$ & $0.15 \pm 0.04$ & & C vs. $A U=<0.001$ \\
\hline Median & 0.31 & 0.27 & 0.16 & & $A D$ vs. $A U=<0.001$ \\
\hline
\end{tabular}

$\mathrm{V}, \mathrm{A}$, and V/A slope of speech ABR. There was significant statistical difference of waves $\mathrm{C}$ and $\mathrm{E}$ among the study groups and highly statistical significant differences of waves D, F, and $\mathrm{O}$.

Pairwise comparisons between the three study groups was done using the Mann Whitney test for variables that showed statistical significant difference in the Kruskal Wallis test. On comparing the ADHD and control groups, only wave $\mathrm{O}$ showed a statistical significant difference. For the autism group, however, there was a significant statistical difference regarding waves $\mathrm{C}$ and $\mathrm{E}$ compared to controls and a highly statistical significant difference for waves
$\mathrm{D}, \mathrm{F}$, and $\mathrm{O}$. There was a significant statistical difference when ADHD was compared to the autism group regarding waves $\mathrm{C}, \mathrm{E}, \mathrm{F}$, and $\mathrm{O}$ and a highly statistical significant difference regarding wave $\mathrm{D}$ (Table 3 ).

Amplitude of waves A and C showed a statistically significant difference between the three studied groups. There was also a highly statistical difference regarding waves $D$, $\mathrm{E}, \mathrm{F}$, and $\mathrm{O}$ among the three groups. There was no significant difference regarding wave $\mathrm{V}$.

Pairwise comparisons between the different groups showed a statistically significant difference when controls were 
Table 4. P300 wave latencies and amplitudes among the control and the two study groups

\begin{tabular}{|c|c|c|c|c|c|}
\hline P 300 & Control (C) & ADHD (AD) & Autism (AU) & $\begin{array}{c}\text { P value } \\
\text { (Kruskal Wallis) }\end{array}$ & $\begin{array}{l}\text { Pairwise P value } \\
\text { (Mann Whitney) }\end{array}$ \\
\hline \multicolumn{6}{|l|}{ Latency (ms) } \\
\hline Range & $306-357$ & $303-475$ & $391-490$ & $<0.001$ & $C$ vs. $A D=0.001$ \\
\hline Mean \pm SD & $330.8 \pm 15.75$ & $394.67 \pm 55.08$ & $436.21 \pm 29.05$ & & C V V. $A U=<0.001$ \\
\hline Median & 330.0 & 402.0 & 434.5 & & $A D$ vs. $A U=\mathbf{0 . 0 4 6}$ \\
\hline \multicolumn{6}{|c|}{ Amplitude ( $\mu v)$} \\
\hline Range & $7.32-16.71$ & $6.67-16.93$ & $4.77-8.57$ & $<0.001$ & C vs. $A D=0.15$ \\
\hline Mean $\pm S D$ & $11.5 \pm 2.92$ & $10.01 \pm 2.92$ & $6.62 \pm 1.34$ & & C vs. $A U=<0.001$ \\
\hline Median & 11.46 & 9.11 & 6.22 & & $A D$ vs. $A U=<0.001$ \\
\hline
\end{tabular}

compared to the ADHD group regarding waves $\mathrm{A}$ and $\mathrm{C}$ and a highly statistical significant difference regarding wave $\mathrm{O}$.

Comparison of the control and autistic groups showed a statistically significant difference regarding wave $\mathrm{A}$ and a highly statistical significant difference regarding waves $C$, $\mathrm{D}, \mathrm{E}, \mathrm{F}$, and $\mathrm{O}$.

Comparison of the autism and ADHD groups showed statistically significant results regarding waves $\mathrm{C}, \mathrm{D}$, and $\mathrm{E}$ and highly statistically significant results regarding waves $\mathrm{F}$ and $\mathrm{O}$.

\section{P300 test results}

Table 4 shows highly statistical significant difference between all groups in P300 latency and amplitude measures. Pairwise comparisons showed significant statistical results when ADHD was compared to controls regarding P300 latency and highly statistical significant results when the autism group was compared to controls. The ADHD and autistic groups also showed statistical significant results when compared together $(p=0.002)$.

There was a highly statistically significant difference in P300 amplitude between the control group and the autism group and between the ADHD group and the autism group, but no significant difference found on comparing ADHD group to controls. Age was correlated to P300 latency and amplitude and showed statistically a significant negative relationship in the control group only. No statistical significant correlation was found between wave latencies of speech evoked $\mathrm{ABR}$ and age in any of the control or study groups.

\section{Discussion}

A major aim of this work was to investigate whether neurodevelopmental disorders with different etiologies had different auditory function profiles which in turn could be used as a benchmark in assessment and rehabilitation of the disorders.

In the click-evoked ABR test, we found no statistically significant difference in the absolute peak latencies of waves in ADHD children compared to the control group, a result which indicates normal encoding of the onset of transient acoustic stimuli. These findings are consistent with those of Schochat et al. [14] and Vaney et al. [15] who reported that all ADHD subjects had normal ABRs. In contrast, other studies have found prolonged latencies of waves III and V in children with ADHD compared with controls [16,17].

Despite having normal brainstem responses to click stimuli, the present study showed that children with ADHD had abnormal subcortical encoding of speech, as indicated by a statistically significant delay in the offset responses of S_ABR (wave O). Furthermore, we found a significant reduction in amplitudes of waves $\mathrm{A}$ and $\mathrm{C}$ as well as the offset wave $\mathrm{O}$ in ADHD children. Johnson et al. [18] reported that amplitude measures signify the robustness with which the brainstem nuclei respond to acoustic stimulation, which appeared to be affected in this study.

As evident from this work, subcortical processing of auditory information in the brain stem was also impaired in autistic children who showed statistically significant delay in waves C, D, E, F, and O of S_ABR. Thus impairment in this group was not only limited to the onset and offset responses but was also obvious in the FFR in the delay of waves D and F. In addition, statistically significant wave reduction was detected in the amplitudes of waves $\mathrm{A}, \mathrm{C}, \mathrm{D}, \mathrm{E}, \mathrm{F}$, and $\mathrm{O}$.

These results are in agreement with Russo et al. 2009 [19] who reported that children with autism exhibited deficits in both the neural synchrony (timing) and phase locking (frequency encoding) of speech sounds, despite normal click-evoked brainstem responses. They also exhibited reduced magnitude and fidelity of speech-evoked responses and greater degradation of responses by background noise in comparison to typically developing controls. Thus, the transduction of speech is disrupted due to an inability to accurately process either filter cues, which help to distinguish between consonants and vowels, or source cues, which help to determine speaker identity and intent. They also claimed that these data support the idea that abnormalities in the brainstem processing of speech contribute to language impairment in autism. 
Although there were differences between the control and autistic groups with respect to brainstem processing of speech stimuli, all subjects exhibited normal processing of non-speech (click) stimuli, which is in agreement with some studies $[19,20]$. Several studies have reported that this result is consistent with data from cortical evoked potentials in autism subjects which indicates that the speechlike property of a stimulus predisposes it to abnormal processing [21-24].

It has been pointed out that children with poor temporal resolution do not have an overall neural processing deficit, but rather a deficit specific to the encoding of certain acoustic cues in speech [18]. Speech understanding therefore relies on the ability to attach meaning to rapidly fluctuating changes of both the temporal and spectral information found in consonants and vowels [18]. It would seem that for this to happen properly, the auditory system must first accurately encode these time-varying acoustic cues, so that speech perception difficulties, which often co-occur in children with poor temporal resolution, may be due to neural encoding deficits in the auditory brainstem [18].

Our results indicate a highly statistically significant difference in P300 latency between the ADHD group and the control group, whereas no significant difference was detected in the amplitudes. Several studies support this delay in P300 latency [14,17,25-27]. It is concluded that P300 latency reflects the timing involved in the categorization of stimuli; therefore if there is a delay this may indicate a defect in the cerebral processing of attention and a reduction in the speed of processing, as is the case in children with ADHD [28].

Although the ADHD literature shows a considerable level of consistency, P300 amplitude is a point of contention, with variable findings. According to the present study, no statistically significant amplitude reduction was found in ADHD subjects, a finding in agreement with several studies [28-31]. However, Puente and colleagues [17] reported decreased P300 amplitude in ADHD. This has been further supported by Idiazábal et al. [32], Senderecka et al. [33], and Tsai et al. [27]. It has been lately concluded that P300 amplitude is heterogeneous in ADHD. The neurophysiological findings detected in brainstem and P300 timing in ADHD is most likely not attributable to maturational deficits. This is evident by our finding that there is no statistically significant Pearson correlation between age and the different measures of speech ABR and P300 in the two groups.

The P300 results in the autistic group showed a delayed wave latency and a diminished amplitude. This is in agreement with Hoeskma et al. [34], Salmond et al. [35], and Sokhadze et al. [36]. The reduction in P300 amplitude is suggested to reflect impaired updating of infrequent or unexpected auditory information in context (Lincoln et al. [37]). In the present study, the autistic group had the most delayed latencies in speech ABR waves and P300 together with the least amplitudes.

Interestingly, we noticed that some autistic children showed interest in listening to the stimulus and became more restful after putting on the headphones, which was in contrast to their agitation during preparation and electrode placement. Other researchers have observed that this population shows a special interest to music and nonspeech sounds. Furthermore, they have suggested that the enhanced pitch perception in autism might account for the impairment in language $[38,39]$.

\section{Conclusions}

- Autism and ADHD patients showed varying levels of impairment in auditory processing of speech stimuli and P300 parameters.

- The autistic group showed the greatest latencies in speech ABR waves and P300, and had the least amplitude.

Deficits detected along the auditory system seem to have a direct impact on behavior, language development, and cognition and thus should be taken into consideration when tailoring management plans for neurodevelopmental disorders.

\section{Acknowledgment}

We thank the nurses and staff at the special needs and autism disorder clinic, National Research Center, and those at the Audiology unit of Cairo University.

\section{References:}

1. van de Vondervoort II, Gordebeke PM, Khoshab N, Tiesinga $\mathrm{PH}$, Buitelaar JK et al. Long non-coding RNAs in neurodevelopmental disorders. Front Mol Neurosci, 2013; 30(6): 53.

2. Brooks-Kayal A. Epilepsy and autism spectrum disorders: are there common developmental mechanisms? Brain Dev, 2010; 32(9): 731-8.

3. Hattier MA, Matson JL, Belva BC, Horovitz M. The occurrence of challenging behaviours in children with autism spectrum disorders and atypical development. Dev Neurorehabil, 2011; 14(4): 221-9.

4. Boddaert N, Belin P, Chabane N, Poline JB, Barthelemy C, Mouren-Simeoni MC. Perception of complex sounds: abnormal pattern of cortical activation in autism. Am J Psychiatry, 2003; 160(11): 2057-60.
5. Russo N, Zecker S, Trommer B, Chen J, Kraus N. Effects of background noise on cortical encoding of speech in autism spectrum disorders. J Autism Dev Disord, 2009; 39(8): 1185-96.

6. Lo-Castro A, D’Agati E, Curatolo P. ADHD and genetic syndromes. Brain Dev, 2011; 33(6): 456-61.

7. Lee DO, Ousley OY. Attention-deficit hyperactivity disorder symptoms in a clinic sample of children and adolescents with pervasive developmental disorders. J Child Adolesc Psychopharmacol, 2006; 16: 737-46.

8. Musiek F, Chermak G. Three commonly asked questions about central auditory processing disorders: Management. American Journal of Audiology, 1995; 4(1): 15-8. 
9. American Psychiatric Association (APA) Diagnostic and manual of mental disorders, fourth edition (DSM-IV). Washington, (DC): American Psychiatric Association, 1994.

10. Conners CK, Sitarenios G, Parker JD, Epstein JN. The revised Conners' Parent Rating Scale (CPRS-R): factor structure, reliability, and criterion validity. J Abnorm Child Psychol, 1998; 26(4): 257-68.

11. Lord C, Rutter M, Le Couteur A. Autism Diagnostic Interview - Revised: a revised version of a diagnostic interview for caregivers of individuals with possible pervasive developmental disorders. J Autism Dev Disord, 1994; 24(5): 659-85.

12. Schopler E, Reichler RJ, DeVellis RF, Daly K. Toward objective classification of childhood autism: Childhood Autism Rating Scale (CARS). J Autism Dev Disord, 1980; 10: 91-103.

13. Akhoun I, Moulin A, Jeanvoine A. Speech auditory brainstem response (speech abr) characteristics depending on recording conditions, and hearing status: An experimental parametric study. J Neurosci Methods, 2008; 175: 196-205.

14. Schochat E, Scheuer CI, Andrade ER. ABR and auditory P300 findings in children with ADHD. Arq Neuropsiquiatr, 2002; 60: $742-7$.

15. Vaney N, Anjana Y, Khaliq F. No auditory conduction abnormality in children with attention deficit hyperactivity disorder. Funct Neurol, 2011; 26(3): 159-63.

16. Azzam H, Hassan D. Auditory brainstem timing and cortical processing in attention deficit hyperactivity disorder. Current Psychiatry, 2010; 17(1): 15-21.

17. Puente A, Ysunza A, Pamplona M, Silva-Rojas A, Lara C. Short latency and long latency auditory evoked responses in children with attention deficit disorder. Int J Pediatr Otorhinolaryngol, 2002; 62: 45-51.

18. Johnson KL, Nicol T, Kraus N. The brainstem response to speech: a biological marker of auditory processing. Ear Hear, 2005; 26: 424-34.

19. Russo N, Zecker S, Trommer B, Chen J, Kraus N. Effects of background noise on cortical encoding of speech in autism spectrum disorders. J Autism Dev Disord, 2009; 39: 1185-96.

20. Tas A, Yagiz R, Tas M, Esme M, Uzun C, Karasalihoglu A. Evaluation of hearing children with autism by using TEOAE and ABR. Autism, 2007; 11(1): 73-9.

21. Jansson-Verkasalo E, Ceponiene R, Kielinen M, Suominen K, Jantti V, Linna SL. Deficient auditory processing in children with Asperger syndrome, as indexed by event-related potentials. Neurosci Lett, 2003; 338(3): 197-200.

22. Boddaert N, Chabane N, Belin P, Bourgeois M, Royer V, Barthelemy C. Perception of complex sounds in autism: abnormal auditory cortical processing in children. Am J Psychiatry, 2004; 161(11): 2117-20.

23. Kasai K, Hashimoto O, Kawakubo Y, Yumoto M, Kamio S, Itoh K. Delayed automatic detection of change in speech sounds in adults with autism: a magnetoencephalographic study. Clin Neurophysiol, 2005; 116(7): 1655-64.

24. Lepistö T, Silokallio S, Nieminen-von Wendt T, Alku P, Näätänen R, Kujala A. Auditory perception and attention as reflected by the brain event-related potentials in children with Asperger syndrome. Clin Neurophysiol, 2006; 117: 2161-71.
25. Lazzaro I, Gordon E, Whitmont S, Meares R, Clarke S. The modulation of late component event related potentials by prestimulus EEG theta activity in ADHD. Int J Neurosci, 2001; 107: 247-64.

26. Ozdag MF, Yorbik O, Ulas UH, Hamamcioglu K, Vural O. Effect of methylphenidate on auditory event related potential in boys with attention deficit hyperactivity disorder. Int J Pediatr Otorhinolaryngol, 2004; 68: 1267-72.

27. Tsai ML, Hung KL, Lu HH. Auditory event-related potentials in children with attention deficit hyperactivity disorder. Pediatr Neonatol, 2012; 53(2): 118-24.

28. Barry RJ, Clarke AR, McCarthy R, Selikowitz M, Brown CR, Heaven PC. Event-related potentials in adults with attentiondeficit/hyperactivity disorder: an investigation using an intermodal auditory/visual oddball task. Int J Psychophysiol, 2009; 71(2): 124-31.

29. Anjana Y, Khaliq F, Vaney N. Event-related potentials study in attention deficit hyperactivity disorder. Funct Neurol, 2010; 25: 87-92.

30. Groom MJ, Bates AT, Jackson GM, Calton TG, Liddle PF, Hollis C. Event-related potentials in adolescents with schizophrenia and their siblings: a comparison with attention-deficit/hyperactivity disorder. Biol Psychiatry, 2008; 63(8): 784-92.

31. Roca P, Mulas F, Presentación-Herrero MJ, Ortiz-Sánchez P, Idiazábal-Alecha MA, Miranda-Casas A. Cognitive evoked potentials and executive functions in children with attention deficit hyperactivity disorder. Rev Neurol, 2012; 54(1): S95-103.

32. Idiazábal Alecha M, Palencia Taboada AB, Sangorrín J, Espadaler-Gamissans JM. Cognitive evoked potentials in the hyperactivity attention deficit disorder. Rev Neurol, 2002; 34: 301-5.

33. Senderecka M, Grabowska A, Gerc K, Szewczyk J, Chmylak R. Event-related potentials in children with attention deficit hyperactivity disorder: an investigation using an auditory oddball task. Int J Psychophysiol, 2012; 85(1): 106-15.

34. Hoeksma MR, Kemner C, Kenemans JL, van Engeland H. Abnormal selective attention normalizes P3 amplitudes in PDD. J Autism Dev Disord, 2006; 36(5): 643-54.

35. Salmond CH, Vargha-Khadem F, Gadian DG, de Haan M, Baldeweg T. Heterogeneity in the patterns of neural abnormality in autistic spectrum disorders: evidence from ERP and MRI. Cortex, 2007; 43(6): 686-99.

36. Sokhadze E, Baruth J, Tasman A, Sears L, Mathai G, El-Baz A, Casanova MF. Event-related potential study of novelty processing abnormalities in autism. Appl Psychophysiol Biofeedback, 2009; 34(1): 37-51.

37. Lincoln AJ, Courchesne E, Harms L, Allen M. Contextual probability evaluation in autistic, receptive developmental language disorder, and control children: event-related brain potential evidence. J Autism Dev Disord, 1993; 23(1): 37-58.

38. Kuhl PK, Coffey-Corina S, Padden D, Dawson G. Links between social and linguistic processing of speech in preschool children with autism: behavioral and electrophysiological measures. Dev Sci, 2005; 8(1): F1-F12.

39. O'Connor K. Auditory processing in autism spectrum disorder: a review. Neurosci Biobeh Rev, 2012; 36(2): 836-54. 